\title{
DOI 10.17150/2308-6203.2021.10(3).500-513
}

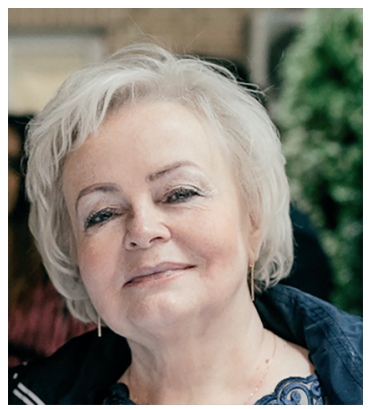

\section{Фролова Татьяна Ивановна}

Доктор филологических наук, профессор

Кафедра периодической печати, фракультет

журналистики, Московский государственный университет имени М.В. Ломоносова, г. Москва, Российская Федерация, e-mail: t_frolova@bk.ru

\section{Tatiana I. Frolova}

D.Sc. in Philology, Professor

Department of Print Media, Faculty of Journalism, Lomonosov Moscow State University, Moscow, Russian Federation, e-mail: t_frolova@bk.ru

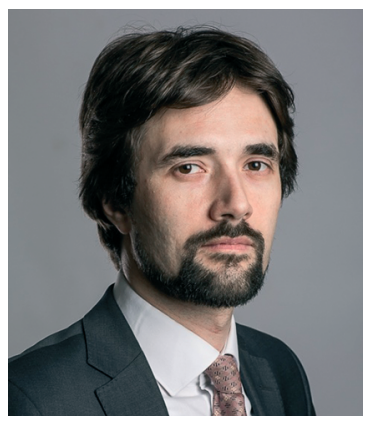

\section{Гатилин Александр Сергеевич \\ Соискатель}

Кафедра периодической печати, фракультет

журналистики, Московский государственный университет имени М.В. Ломоносова, г. Москва, Российская Федерация, e-mail: gatilin@mail.ru

Alexander S. Gatilin

PhD Student

Department of Print Media, Faculty of Journalism, Lomonosov Moscow State University, Moscow, Russian Federation, e-mail: gatilin@mail.ru

\section{Социальные проекты муниципальных СМИ как инструмент развития местных сообществ и территорий: стартовые особенности}

\footnotetext{
Аннотация. Статья посвящена опыту реализации социальных проектов журналистами муниципальных СМИ России. Активность, направленная на развитие местных сообществ и решение социальных проблем, занимает значительное место в повседневной деятельности местных редакций: журналисты инициируют и организуют общественные дискуссии по актуальным вопросам, отстаивают права малообеспеченных семей и ветеранов Великой отечественной войны, собирают деньги на операции и помогают малоимущим. В статье на основе анализа описаний 126 социальных проектов местных СМИ и 25 структурированных анкет, заполненных инициаторами социальных проектов, обсуждаются фракторы, влияющие на принятие решений о реализации социальных проектов. Авторы предлагают классифицировать социальные инициативы журналистов как проекты, направленные на социальную защиту и социальное развитие, определяют 15 типовых вариантов инициирования проектов, формулируют и аргументируют разделение на две группы проектов (реактивные и проактивные), осмысляют единоличный и коллективный способы принятия решений о старте социального проектирования, приводят примеры конструктивных и неконструктивных взаимоотношений журналистов с представителями власти, бизнеса, НКО в инициировании и осуществле-
} 
нии социальных проектов. Авторы фриксируют, что журналисты и местные жители в большей степени, чем представители власти, бизнеса, НКО выступают инициаторами решения социальных проблем и развития местного сообщества, что позволяет предположить значимость метафункции формирования гражданского общества как следствия реализации социальных проектов СМИ. На основе полученных результатов исследования авторы утверждают необходимость поддержки социальных журналистских инициатив со стороны государственных органов власти всех уровней, представителей НКО, бизнеса и исследовательского сообщества.

Ключевые слова. Гражданское общество, социально-организаторская фуннция СМИ, гражданская журналистика, социальный проект, местное сообщество.

Информация о статье. Дата поступления 30 июня 2021 г;; дата принятия к печати 25 августа 2021 г;; дата онлайн-размещения 21 сентября 2021 г.

\title{
Social Projects by Local Media as a Tool for the Development of Local Communities: Starting Points
}

\begin{abstract}
Despite the widespread concepts of "civic journalism", "social journalism", "community-centered journalism", "citizens journalism", social projects implemented by the local media remain insufficiently studied. Journalists initiate and organize public discussions on hot issues, defend the rights of low-income families and World War II veterans, raise money for operations. The current research conducted at the School of Journalism at Lomonosov Moscow State University examined the phenomenon of journalists' participation in solving social issues of local communities. We analyzed the descriptions of 126 social projects by local media and 25 questionnaires. The article discusses the factors that influence decision-making on the implementation of social projects. The authors present the themes, aims of social projects, and 15 types of initiation of social projects, give examples of constructive and nonconstructive relations between journalists and representatives of authorities, business, NGOs in initiation and implementation of social projects. The authors noted that journalists and citizens, to a greater extent than representatives of local authorities, business, NGOs, are initiators of solving social problems and developing the local community. The findings appear to demonstrate that by initiating and realizing social projects, local media are fulfilling the meta-function of the development of civil society. The authors highlight the necessity of supporting journalistic initiatives.

Keywords. Civil society, civic journalism, public journalism, participatory culture, local community, local media, social project, social activity.

Article info. Received June 30, 2021; accepted August 25, 2021; available online September 21, 2021.
\end{abstract}

\section{Введение}

Стремительная трансформация практик медиапотребления и развитие информационных технологий, а также последовательное становление граж- данского общества в России вносят значительные коррективы в деятельность муниципальных СМИ. Наряду с представителями органов власти, бизнеса и некоммерческих организа- 
ций журналисты активно участвуют в жизни местных сообществ. Часто в редакции обращаются жители, оказавшиеся в ситуации, когда чиновники в помощи отказали, а некоммерческих организаций нужного профиля на территории нет. СМИ становятся «скорой социальной помощью» и учатся эффективно решать проблемы граждан и всего местного сообщества - на достижениях и просчетах.

Ирина Фомичева [1] обращает внимание на необходимость поновому посмотреть на отношения журналистов и аудитории: должен измениться спектр ролей журналиста, который не может быть лишь проповедником, просветителем, расследователем, репортером, аналитиком. Автор уверена, что необходимо рассматривать роли организатора, медиатора, модератора и учить журналистов этим ролям. Размышляя об утрате журналистами монополии на распространение информации, Елена Вартанова [2] обозначает новые возможные роли журналистов - в первую очередь, роль модератора социальных дискуссий. Ирина Демина указывает, что краудфандинговые площадки (которыми могут быть муниципальные площадки), решают вопросы коммуникации, взаимодействия, создания комьюнити, примеры «коллективного разума»[3].

Трансформация журналистских практик и подходов происходит не только в России. Стивен Барнетт [4] описывает четыре актуальных вида деятельности СМИ, которые вносят вклад в демократизацию местных сообществ: информирование (informing), репрезентация (representing), проведение кампаний (campaining) и обращение к представителям власти (interrogating). Поми- мо традиционного информирования аудитории о значимых событиях, журналисты, по мнению Барнетта, организуют обратную связь с властью, представляя мнения граждан по актуальным вопросам на своих страницах и в эфире, тем самым осуществляя функцию репрезентации.

Стоит отметить, что социально ориентированной и человекоцентричной российская журналистика была на протяжении нескольких столетий, а деятельность «коллективного организатора» характерна отнюдь не только для советского периода нашей истории, но имеет мощные культурно-исторические корни [5]. Представляется целесообразным, сохраняя гуманистический характер общественно-политической журналистики в России, предложить к использованию новые практики вовлечения аудитории в решение социальных проблем и развитие местных сообществ.

Исследуя деятельность журналистов и роль СМИ в развитии институтов гражданского общества, мы опирались на фундаментальные труды и теоретические разработки российских и зарубежных ученых [6-13]. Значимым ориентиром для анализа институциональных особенностей функционирования СМИ в демократическом обществе и форм вовлечения аудитории стали концепции социальной ответственности СМИ [14], конструкционизма [15; 16], гражданской журналистики [17-19], коллаборативной журналистики ${ }^{1}$, журналистики решений ${ }^{2}$,

${ }^{1}$ What is Collaborative Journalism? Peжим доступа: https://collaborativejournalism. org/what-is-collaborative-journalism/

2 Who We Are. Solutions Journalism. Peжим доступа: https://www.solutionsjournalism. org/who-we-are/mission 
журналистики сообществ (соmmunity-centeredjournalism) [20]. В Pocсии наибольшее распространение приобрели концепции социальной журналистики [21], журналистики соучастия [22] и партиципарной журналистики [1].

Вместе с тем, феномен социального проектирования, которое осуществляют муниципальные СМИ, представляется недостаточно изученным. В этом отношении важна работа Надежды Хлебниковой [23], которая рассматривала социальные инициативы местных газет в контексте принципов гражданской журналистики и убедительно показала, что суть гражданской журналистики нельзя описать в логике классических информирующих медиа, необходимо выйти за эти рамки.

Исследование, проводимое на кафедре периодической печати фракультета журналистики МГУ имени М.В. Ломоносова, ставит своей целью разработку нормативной модели реализации социальных журналистских проектов, направленных на решение социальных проблем и развитие местных сообществ. Подобная модель позволит проводить анализ существующих практик и разрабатывать рекомендации по совершенствованию социальных инициатив редакций местных СМИ.

В настоящей статье представлена часть результатов исследования. Авторы рассматривают вопросы целеполагания, а также технологические аспекты инициирования общественных изменений журналистами местных СМИ, предлагают рекомендации по совершенствованию взаимодействия субъектов общественных процессов в ходе реше- ния социальных проблем и развития местных сообществ.

\section{Методология}

Для целей нашего исследования необходимо обратить внимание на то, что социальная активность журналистов имеет очевидные признаки проектной деятельности. Одно из наиболее распространенных определений в теории менеджмента гласит, что проект - это временное предприятие, предназначенное для создания уникальных продуктов, услуг или результатов, характеризуемое наличием сроков реализации, результатов проекта (уникальным продуктом или услугой), направленностью на достижение целей и (или) решение проблемы. Успешность проекта определяется степенью реализации поставленной цели с учетом имеющихся ресурсных ограничений [24]. Обратим внимание, что это определение по сути близко «формуле» действенности журналистской работы, данное Евгением Прохоровым [5].

В настоящей статье мы обратимся к начальным этапам (профессиональным действиям, операциям) проектирования: обнаружение проблем и принятие решения о запуске социального проекта. Грамотный старт проекта во многом определяет меру его успешности. Мы определяем социальные проблемы, которые становятся поводом для инициирования медиапроектов как недостаточное, неприемлемое качество состояния рассматриваемого объекта, процесса или явления, которое может быть выражено качественными или количественными индикаторами. Социальные проекты СМИ в нашем понимании - это многокомпо- 
нентная деятельность журналистов, направленная на решение социальных проблем местного сообщества посредством его непосредственного вовлечения и выходящая за пределы традиционно понимаемых авторских функций.

Один из авторов исследования принимал непосредственное участие в организации конкурсов и дискуссий по теме социального проектирования муниципальными СМИ; провел ряд интервью с журналистами и редакторами, реализовавшими свои проекты"; был непосредственным организатором межрегиональных журналистских проектов ${ }^{5}$. Все это позволило выстроить конструктивные отношения с участниками исследования и сформировать необходимую методику исследования.

Представляя некоторые результаты нашего исследования, обратимся к характеристике его методи-

${ }^{3}$ А. Гатилин с 2014 г. организует Всероссийский конкурс «Семья и будущее России»; на конкурс было представлено более 40000 журналистских материалов на социальную тематику. Режим доступа: https://fap.ru/presscenter/news/startuet-vserossiyskiy-konkursdlya-zhurnalistov-semya-i-budushcheerossii-2020.

${ }^{4}$ А. Гатилин публикует материалы о деятельных муниципальных журналистах в рубрике «Близко к сердцу» портала «Такие дела». Режим доступа: https://takiedela. ru/news/2020/07/03/lyudmila-keybol/ и https:// takiedela.ru/news/2020/11/07/tak-zhit-nelzya.

5 А. Гатилин организовывал межрегиональные журналистские проекты «Быть отцом!», «Социальный мониторинг. ДЦП», «Идеальная Россия? Представь!», «Скорая журналистская помощь». Режим доступа: https://rusbatya.ru/byit-ottsom/ ; https://expert. ru/russian_reporter/2018/03/10-problem-geroicheskih-semej/ ; https://expert.ru/russian_reporter/2018/10/rossiya-obraz-buduschego/ ; https:// novayagazeta.ru/articles/2020/05/05/85228skoraya-zhurnalistskaya-pomosch. ческой стороны, которая включала следующие действия:

- предварительный разведывательный структурированный опрос 39 руководителей социальных проектов СМИ;

- проведение дискуссий с участием 40 журналистов о практике реализации социальных проектов местных СМИ;

- контент-анализ описаний 126 социальных проектов 65 СМИ из 36 регионов России;

- структурированный опрос (онлайн-анкетирование) руководителей 25 социальных проектов из числа 126 инициатив.

В статье использованы ответы на вопросы о том, как появилась идея реализации проекта, как принималось решение о том, что редакция возьмется за реализацию проекта, на чью помощь рассчитывали журналисты, и кто по факту помог. Помимо указанных вопросов, лидеры социального проектирования рассказали о том, как определили цель проекта, как анализировали необходимые ресурсы, как использовали социальные сети и иные онлайнплатформы, как оценивать эффективность реализации социальных проектов СМИ, в какой поддержке они нуждаются.

\section{Основные результаты исследования}

\section{Целевые особенности проектов}

Предваряя представление результатов анализа особенностей инициирования социальных проектов СМИ, обозначим тематическое и целевое разнообразие исследованных на первом этапе 126 проектов. Исходя из целей, характера 
необходимых действий и ожидаемых результатов, различных типов объектов воздействия, мы выделили два направления: проекты, ориентированные на социальное развитие и проекты, направленные на социальную защиту. Результаты исследования 126 социальных проектов показали, что функция социальной защиты (помощь людям в беде) пока количественно преобладает (54 \%). Вместе с тем $46 \%$ проектов, направленных на социальное развитие, - это серьезный задел для дальнейшей системной работы. Считаем целесообразным обратить внимание на сделанный ранее прогноз [21] о том, что содержание социальных инициатив СМИ будет развиваться, а организаторская активность будет направлена не только на защиту и помощь, но и на социальное развитие, на более полную реализацию человеческого капитала. Полученные нами результаты фрактически подтвердили верность этого прогноза, что позволяет ожидать дальнейшего роста числа проектов, направленных на социальное развитие.

\section{Инициаторы социальных проектов СМИ}

Среди собранных нами двадцати пяти структурированных анкет (их адресаты выделены из общего перечня проектов) были представлены проекты, направленные как на социальную защиту, так и на социальное развитие. Анкета включала 19 вопросов, связанных с организационно-технологическими аспектами социального проектирования. Мы получили возможность сорормировать многогранную и тематически разнообразную классификацию социальных проектов по субъектам, обозначившим проблему, на решение которой был направлен социальный проект СМИ.

В самом широком варианте классификации в качестве единиц анализа мы выделили:

- реактивные социальные проекты (редакции реагируют на внешнюю инициативу);

- проактивные социальные проекты (журналисты сами выступают инициаторами общественных изменений).

На рис. 1 представлен анализ проектов, детальные описания ко-

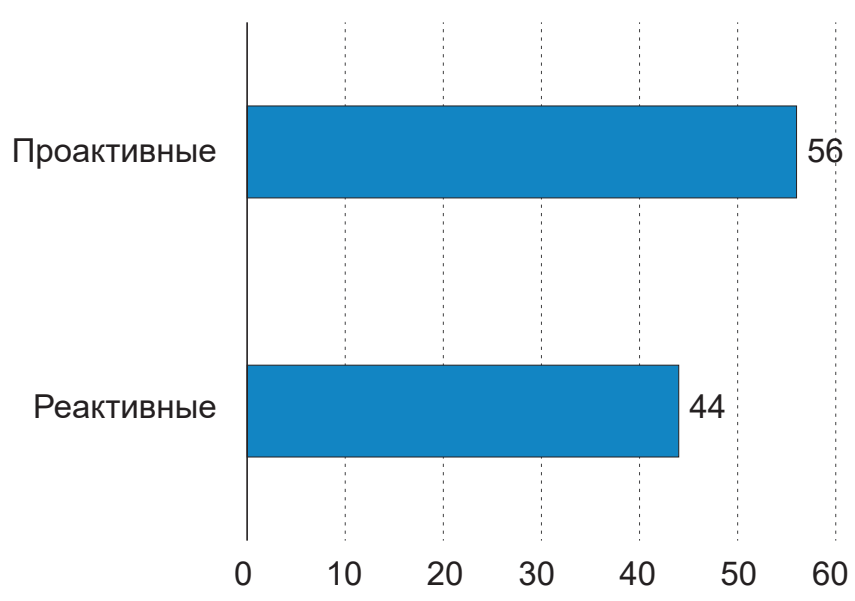

Рис. 1. Проекты и их инициаторы 
торых были собраны в ходе анкетирования их инициаторов. Исследование показало, что журналисты обладают существенным потенциалом для инициирования общественных изменений.

Рассмотрим более детально базовый этап определения, обнаружения проблемы. В качестве внешних инициативных субъектов мы рассматриваем отдельных читателей, профильные сообщества, бюджетные учреждения, НКО, бизнес и органы власти. В случае проактивных социальных проектов инициаторами общественных изменений выступали журналисты и редакторы.

На основе ответов на первый вопрос анкеты «Как появилась идея реализации проекта?» мы выделили пятнадцать вариантов обнаружения проблемы в зависимости от типа инициативного субъекта и социокультурных обстоятельств.

Проактивные проекты (инициативный субъект - журналисты) возникают в следующих обстоятельствах:

1. Реализация текущих долгосрочных проектов (традиционная публикация имен ветеранов в газете к Дню Победы переросла в монументальный проект «Стена памяти» («Выксунский рабочий»)).

2. Взаимодействие со спикерами по актуальным вопросам (видя, что спорные вопросы не решаются, журналисты создали дискуссионную площадку «Спорный перекресток» («Огни Енисея»)).

3. Разработка новой темы или проекта к памятной дате (к дню памяти Святителя Николая журналисты запустили благотворительный проект для поддержки нуждающихся («Прихопёрье»); к Дню матери жур- налисты преобразили многодетных матерей в ходе акции «День красоты для мамы» («Саткинский рабочий»))

4. Регулярный мониторинг соцcemeй (на личной странице жительницы района обнаружили просьбу помочь со сбором средств на лечение - запустили проект «Юля хочет жить»(«Прихопёрье»).

5. Заимствование идеи проекmа у коллег из федеральных или иных СМИ (проект «День ангела» возник как переосмысление программы федерального телеканала - журналисты стали помогать малообеспеченным семьям, так как детдома на территории района не было («Новое время»)).

6. Обнаружение проблемы в повседневном опыте журналистов (журналист начинает бороться с нежеланием городской администрации следить за открытыми люками («Копейский рабочий»), журналисты возмутились незаконной вырубкой леса вокруг любимого селянами озера и возглавили борьбу за сохранение экологической среды («Уренские вести»)).

7. Реорганизация прошлого опыта в новых условиях (чтобы привлечь молодых читателей, журналисты возобновили работу юнкоров при редакции («Уренские вести»)).

8. Возрождение и продолжение традиций предшественников (легкоатлетическая эстафета на призы газеты («Прихопёрье»)).

Реактивные проекты (инициаторы - внешние субъекты) возникают в следующих обстоятельствах:

1. Отклик на коммерческий заказ (по предложению и при фринансировании местного предприятия проводится благотворительная ярмарка («Выксунский рабочий»)). 
2. Обращение жителей города по вопросам благоустройства (личное обращение читателя в редакцию по поводу опасного участка дороги дало повод для общегородского проекта по мониторингу участков дорог, нуждающихся в ремонте («Прихопёрье»)).

3. Обращение жителей города по личным проблемам (журналисты помогли собрать средства на лекарства и обустроили среду для инвалида («Прихопёрье»)).

4. Обращение местных активных групп граждан (молодые мамочки пожаловались на закрытие молочной кухни - редакция добилась компромиссного решения проблемы («Земля Кстовская»)).

5. Обращение представителей НКО (председатель Общественной палаты обратился в редакцию, чтобы не допустить перевода обслуживания «скорой помощи» в частные руки - журналисты добились решения, устраивающего местных жителей («Копейский рабочий»)).

6. Долгосрочное информационное сотрудничество с НКО (журналисты регулярно рассказывали о работе реабилитационного центра - придумали школу юнкоров для детей с ОВ3 («Шахтинские известия»)).

7. Долгосрочное взаимодействие с государственными органами власти и государственными учреждениями (журналисты взаимодействуют по текущим вопросам с органами опеки - рождается проект «Я жду тебя мама» («Знамя»)).

Мы видим (опыт открытых дискуссий и интервью с инициаторами проектов это подтверждает), что журналисты, обращающиеся в своей работе к запросам и потребностям читателей (и более широко - к нуждам жителей района), имеют разнообразные возможности для выявления социальных проблем и точек роста местного сообщества. Как утверждает Людмила Кейбол, без налаженной обратной связи с земляками редакция с ее небольшим штатом не смогла бы поднимать так много разнообразных актуальных вопросов, волнующих читателей [25].

Близкие к представленным результаты мы получили на этапе анализа 126 социальных проектов в категории «Целевая аудитория» (кто вовлекался в реализацию проекта). На рис 2 представлено, что в

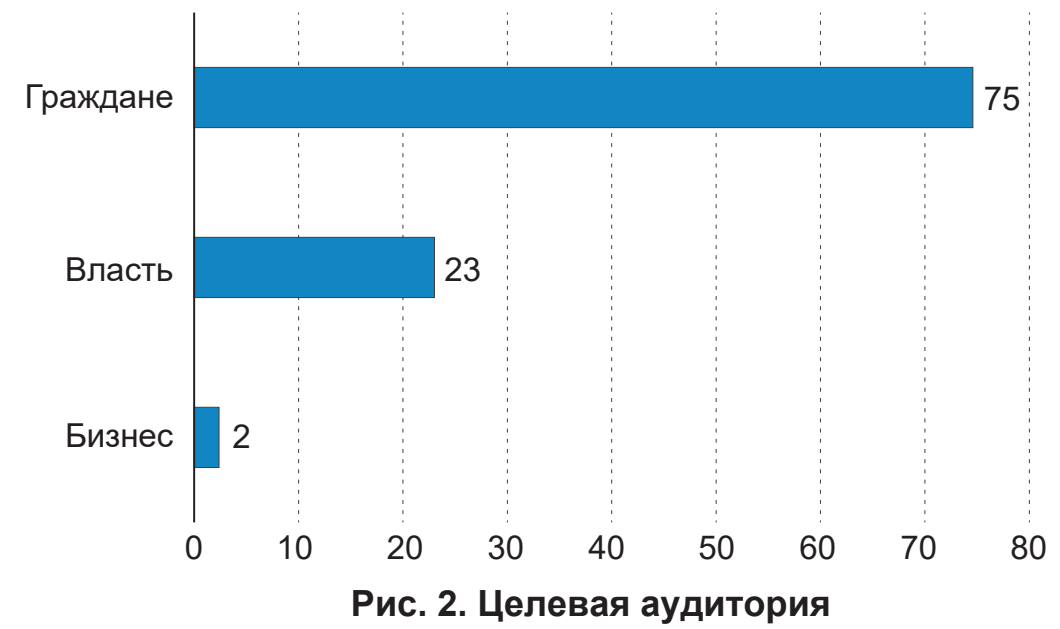


Theoretical and Practical Issues of Journalism, 2021, vol. 10, no. 3, pp. 500-513

подавляющем большинстве случаев журналисты получали основную поддержку от простых граждан.

Можно зафиксировать, что инициаторами общественных изменений часто становятся сотрудники СМИ или жители. В реализации социального проекта они скорее рассчитывают на себя и на других жителей, чем на власти, бизнес и НКО.

\section{Методы принятия решений - cmapme социального проекта}

Рассматривая социальные проекты, представляется важным обратить внимание на методы принятия решения о старте проекта. В самом широком виде единицами анализа могут быть: индивидуальное или коллективное принятие решения о запуске социального проекта.

Социальное проектирование чаще всего представляет собой пример горизонтального, неиерархичного взаимодействия, успех которого во многом зависит от вовлеченности участников проекта, их креативности, ответственности и самостоятельности. На рис. 3 мы видим, что среди рассмотренных в качестве примера двадцати пяти социальных проектов, подавляющее большинство стартовало после коллективного обсуждения.

Мы видим, что дискуссионный процесс составляет важную часть социального проектирования. Вместе с тем представляется целесообразным расширять круг участников обсуждений о целесообразности запуска того или иного проекта, что позволит расширить число участников и повысить степень их вовлеченности в достижение совместно выработанной цели. Также в перспективе у наиболее активных редакций может возникнуть дилемма, какой из актуальных проектов реализовывать с учетом имеющихся ограниченных человеческих, материальных, временных ресурсов. Дискуссионный фрормат может быть полезен в выявлении приоритетов и принятии управленческих решений.

\section{Дискуссия}

Социальные инициативы СМИ вызывают серьезную полемику как

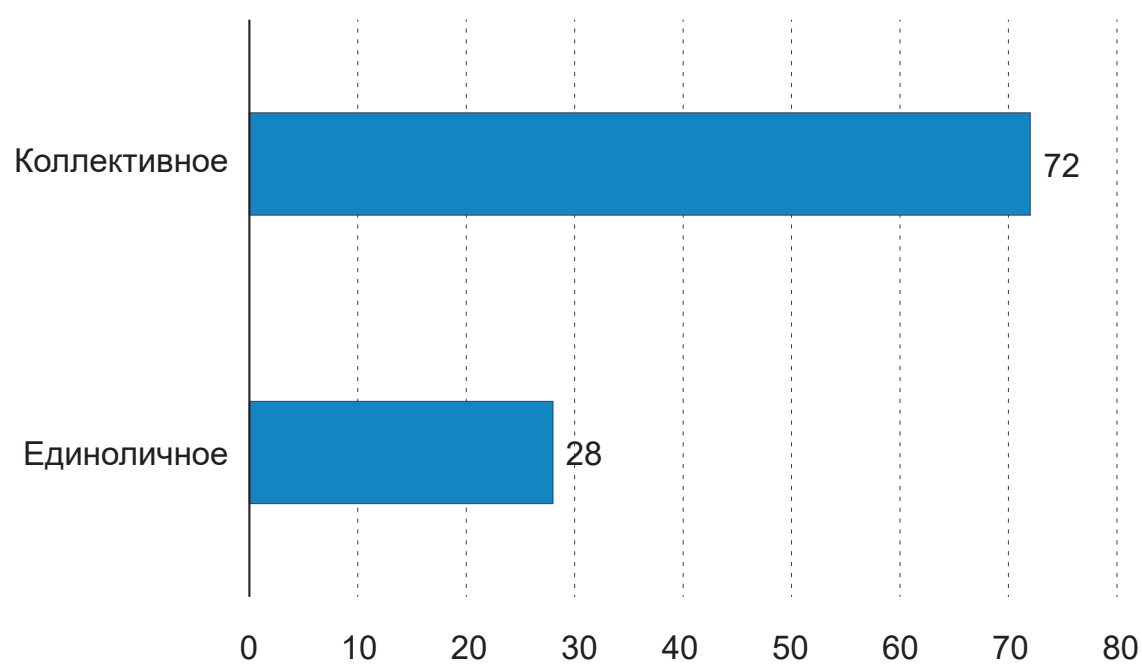

Рис. 3. Методы принятия решения 
в журналистском, так и в научном сообществах. Мы не считаем избыточной и неуместной практику участия редакций районных газет в решении социальных вопросов и развитии местного сообщества. Помимо качественного выполнения профессиональных обязанностей сотрудники СМИ часто имеют активную гражданскую позицию и человеческие качества, не позволяющие пройти мимо человека в беде. На «человековедческие» приоритеты указывает Сергей Корконосенко как на особые качества русской журналистики [26].

Взаимодействие редакции с аудиторией изучала в 1989 г. Луиза Свитич. По итогам анализа деятельности районных газет Киргизии она разработала актуальную и сегодня модель эффективной районной газеты [27]. В ее представлении, это «общенародное демократическое издание, удовлетворяющее потребности и интересы различных групп населения освещающее и анализирующее самые острые проблемы перестройки политической, экономической, социальной и духовной сфер жизни района, помогающее их решению при помощи вовлечения в этот процесс общественного мнения, широких масс, делая их соучастниками революционных преобразований общества». Автор на обширном эмпирическом материале показала, что издания, которые четко ориентированы на концепцию взаимодействия с аудиторией, регулярно изучают общественное мнение и дают ему место на своих страницах, стали очень популярны у читателя. Например, «Сельская новь» Московского района за год увеличила свой тираж вдвое. И наоборот, снизились тиражи у газет, которые придерживаются командно-бюрократических подходов к своей аудитории и сами являются, по сути дела, информационной бюрократией.

Поставленный Луизой Свитич вопрос актуален и сегодня: какую роль будут играть районные газеты в общественной жизни? Многие руководители муниципалитетов хотели бы видеть журналистов исключительно в роли информаторов и пропагандистов, а любую обратную связь от жителей, опубликованную в СМИ, воспринимают «в штыки». Редакторы же понимают, что без вовлечения читателей в производство и распространение контента, в осуществление совместных акций, мероприятий и проектов сохранить, а тем более развивать газеты не получится. «Что толку от вашей писанины, если проблемы не решаются», - часто слышала от читателей подобный вопрос экс-главный редактор газеты «Вперёд» Елена Пивоварова.

В этой связи представляется, что исследователи, журналисты и представители профильных органов власти должны приложить дополнительные усилия к изучению и поддержке социальных журналистских инициатив. Любая инициатива должна развиваться за счет вовлечения новых заинтересованных участников и привлечения необходимых материальных ресурсов. В условиях неблагоприятной внешнеполитической конъюнктуры, снижения уровня доходов граждан, роста социальной апатии и пессимизма особое значение приобретают слова Президента России Владимира Путина о том, что без СМИ гражданское общество мы не построим [28]. 


\section{Выводы}

Результаты проведенного исследования показывают, что муниципальные газеты имеют значительный потенциал в инициировании общественных изменений, решении социальных проблем, консолидации местных сообществ и развитии комфрортной среды обитания. Рассмотренные 126 социальных проектов - это, в большинстве своем, примеры личной или коллективной инициативы журналистов или отклик на просьбы о помощи со стороны местных жителей. Успех в реализации подобных начинаний во многом зависит от мотивации лидеров проектов, их навыков социального проектирования и работы с сетевыми сообществами. Представляется целесообразным проведение дискуссионных площадок (оффлайн и онлайн) для обмена опытом и взаимной поддержки журналистов. Целесообразно также разработать онлайн-курсы для развития необходимых навыков и повышения уровня знаний в сфрерах, связанных с общественным развитием и проектной деятельностью. Немаловажной является поддержка со стороны государственных органов власти. Некоторые СМИ уже зарегистрировали автономные некоммерческие организации для участия в грантовых конкурсах, представляется целесообразным расширять число потенциальных участников различного рода грантовых конкурсов и иных форм поддержки социально значимой деятельности СМИ.

Масштаб феномена социального проектирования, который инициируют и в котором участвуют журналисты районных газет, настолько велик, что требует сотрудничества исследователей различных вузов из разных регионов России. Представляется целесообразным формирование совместных исследовательских программ с участием научных сотрудников, магистрантов, студентов бакалавриата, направленных на проведение исследований с использованием количественных и качественных методов.

\section{СПИСОК ИСПОЛЬЗОВАННОЙ ЛИТЕРАТУРЫ}

1. Фомичева И.Д. СМИ как партиципарные коммуникации : дис. ... д-ра филол. наук : 10.01 .10 / И.Д. Фомичева. - Москва, 2002. - 84 с.

2. Вартанова Е.Л. О необходимости модернизации концепций журналистики и СМИ / Е.Л. Вартанова // Вестник Московского университета. Серия 10: Журналистика. - 2012. - № 1. С. 7-26.

3. Демина И.Н. Медиатизация экономики: аспекты оптимизации экономических медиакоммуникаций в цифровой среде / И.Н. Демина. — DOI 10.17150/2308-6203.2021.10(2).253269 // Вопросы теории и практики журналистики. - 2021. - Т. 10, № 2. - С. 253-269.

4. Barnett $S$. Journalism, Democracy and the Public Interest: rethinking media pluralism for the Digital Age / S. Barnett. — URL: https://reutersinstitute.politics.ox.ac.uk/our-research/ journalism-democracy-and-public-interest.

5. Горчева А.Ю. Нищенство и благотворительность в России / А.Ю. Горчева. - 2-е изд. - Москва, 2013. - 232 с.

6. Прохоров Е.П. Введение в теорию журналистики : учебник / Е.П. Прохоров. — Москва : Аспект Пресс, 2009. - 351 с.

7. Фомичева И.Д. Социология СМИ / И.Д. Фомичева. - Москва : Аспект Пресс, 2012. -360 c.

8. Социология журналистики : учебник / отв. ред. С.Г. Корконосенко. - Москва : Юрайт, 2016. - 421 с. 
9. Газеты средних и малых городов России в 2010-х гг. (результаты опроса редакторов и журналистов) / Л.Г. Свитич, О.В. Смирнова, А.А. Ширяева, М.В. Шкондин. - Москва, 2015. - 277 с.

10. Бережная М.А. Социальные проблемы в фокусе ТВ : учеб. пособие / М.А. Бережная. - Санкт-Петербург : Изд-во С.-Петербург. ун-та, 2017. - 192 с.

11. Иванян Р.Г. Журналистика и социальная работа: природа и опыт институционального взаимодействия (Россия, конец XX - начало XXI веков) : дис. ... канд. полит. наук : 10.01.10 / Р.Г. Иванян. - Санкт-Петербург, 2007. - 291 с.

12. МакКуэйл Д. Журналистика и общество : учебник для журналистов / Д. МакКуэйл. - Москва : МедиаМир, 2014. - 362 с.

13. Normative Theory of the Press / C. Christians, T. Glasser, D. McQuail [et al.]. Urbana : University of Illinois Press, 2009. $-275 \mathrm{p}$.

14. Siebert F.S. Four Theories of the Press / F.S. Siebert, T. Peterson, W. Schramm. Urbana : University of Illinois Press, 1984. - $153 \mathrm{p}$.

15. Spector M. Constructing Social Problems / M. Spector, J.I. Kitsuse. - New York : Routledge, 2001. - 196 p.

16. Ясавеев И.Г. Социальные проблемы и медиа: конструкционистское прочтение / И.Г. Ясавеев. - Саарбрюкен, 2010. - 231 с.

17. Миллер Э.Д. Шарлотский проект. Как помочь гражданам взять демократию в свои руки / Э.Д. Миллер. - Москва : Виоланта, 1998. - 62 с.

18. The idea of public journalism / ed. T.L. Glasser. - New York : TheGuilford Press, 1999. $-229 \mathrm{p}$.

19. Haas T. The pursuit of public journalism / T. Haas. — New York: Routledge, 2012. - 208 p.

20. Wenzel A. Community-Centered Journalism: Engaging People, Exploring Solutions, and Building Trust / A. Wenzel. — Urbana :University of Illinois Press, 2020. - 220 p.

21. Фролова Т.И. Гуманитарная повестка российских СМИ. Журналистика, человек, общество / Т.И.Фролова. - Москва : МедиаМир, 2014. - 352 с.

22. Дзялошинский И.М. Журналистика соучастия. Как сделать СМИ полезными людям / И.М. Дзялошинский. - Москва : Престиж, 2006. - 104 с.

23. Хлебникова Н.В. Гражданская журналистика: к истории становлении термина / H.В. Хлебникова // Медиаскоп. — 2011. - № 3. — URL: http://www.mediascope.ru/node/896.

24. Управление проектами : учебник и практикум / под ред. Е.М. Роговой. -Москва : Юрайт, 2019. - 383 с.

25. Гатилин А.С. «Дурной» пример заразителен». Редактор газеты в Змеиногорске научила жителей проводить расследования и отстаивать свои права / А.С. Гатилин // Такие дела. — 2020. - 03 июля. — URL: https://takiedela.ru/news/2020/07/03/lyudmila-keybol/.

26. Корконосенко С.Г. Теория журналистики: моделирование и применение / С.Г.Корконосенко. - Москва : Логос, 2010. - 247 с.

27. Свитич Л.Г. Журналисты и аудитория. Из социологического архива (19202015 гг.) / Л.Г. Свитич. - Москва : Икар, 2018. - 486 с.

28. Грищенко Н. Путин пообещал ростовскому губернатору помочь разобраться в ситуации с газетой "Вперед"/ Н. Грищенко, Л. Ионова // Российская газета. - 2020. 17 дек. - URL: https://rg.ru/2020/12/17/reg-ufo/putin-poruchil-glave-dona-razobratsia-vdele-redaktora-gazety-iz-batajska.html.

\section{REFERENCES}

1. Fomicheva I.D. Mass Media as participatory communicators. Doct. Diss. Moscow, 2002. 84 p.

2. Vartanova E.L. On the Need to Update the Concepts of Journalism and Media. Vestnik Moskovskogo universiteta. Seriya 10: Zhurnalistika = Moscow University Journalism Bulletin, 2012, no. 1, pp. 7-26. (In Russian).

3. Demina I.N. Mediatization of the Economy: Aspects of Optimizing Economic Media Communications in the Digital Environment. Voprosy teorii $i$ praktiki zhurnalistiki $=$ Theoretical and Practical Issues of Journalism, 2021, vol. 10, no. 2, pp. 253-269. (In Russian). DOI: 10.17150/2308-6203.2021.10(2).253-269. 
4. Barnett S. Journalism, Democracy and the Public Interest: rethinking media pluralism for the Digital Age. Available at: https://reutersinstitute.politics.ox.ac.uk/our-research/journalism-democracy-and-public-interest.

5. Gorcheva A.Yu. Poverty and charity in Russia. $2^{\text {nd }}$ ed. Moscow, 2013. 232 p.

6. Prokhorov E. P. Introduction to the theory of journalism. Moscow, Aspekt Press Publ., 2009. $351 \mathrm{p}$.

7. Fomicheva I. D. Sociology of Mass. Moscow, Aspekt Press Publ., 2012. 360 p.

8. Korkonosenko S.G. (ed.). Sociology of Journalism. Moscow, Yurait, 2016. 421 p.

9. Svitich L.G., Smirnova O.V., Shiryaeva A.A., Shkondin M.V. Newspapers of Middle and Small Russian Towns in 2010s. Moscow, 2015. 277 p.

10. Berezhnaya M.A. Social issues in the focus of TV. Saint Petersburg State University Publ., 2017. 192 p.

11. Ivanyan R.G. Journalism and social work: the nature and experience of institutional interaction (Russia, late XX - early XXI centuries).Cand. Diss. Saint Petersburg, 2007. 291 p.

12. MakKueil D. Journalism and society. Hardcover, Sage, 2013. 256 p. (Russ. ed.: MakKueil D. Journalism and society. Moscow, MediaMir Publ., 2014. 362 p.).

13. Christians C., Glasser T., McQuail D., Nordenstreng K., White R. Normative Theory of the Press. Urbana, University of Illinois Press, 2009. 275 p.

14. Siebert F.S., Peterson T. Schramm W. Four Theories of the Press. Urbana, University of Illinois Press, 1984. 153 p. $196 \mathrm{p}$.

15. Spector M., Kitsuse J.I. Constructing Social Problems. New York, Routledge, 2001.

16. Yasaveev I.G. Social Problems and Media. Saarbryuken, 2010. 231 p.

17. Miller E.D. The Charlotte Project Helping Citizens Take Back Democracy. Sant Petersburg, Florida, 1994. 93 p. (Russ. ed.: Miller E.D. The Charlotte Project Helping Citizens Take Back Democracy. Moscow, Violanta Publ., 1998. 62 p.).

18. Glasser T.L. (ed.). The Idea of Public Journalism. New York, TheGuilford Press, 1999. 229 p.

19. Haas T. The Pursuit of Public Journalism. New York, Routledge, 2012. 208 p.

20. Wenzel A. Community-Centered Journalism: Engaging People, Exploring Solutions, and Building Trust. Urbana, University of Illinois Press, 2020. - 220 p.

21. Frolova T.I. Humanitarian Agenda of Russian Media. Journalism, People, Society. Moscow, MediaMir Publ., 2014. 352 p.

22. Dzyaloshinskii I.M. Partnership Journalism. How to Make Mass Media Useful to People. Moscow, Prestizh Publ., 2006. 104 p.

23. Khlebnikova N.V. Citizen Journalism: History of the Term. Mediaskop = Mediascope, 2011, no. 3. Available at: http://www.mediascope.ru/node/896 (In Russian).

24. Rogova E.M. (ed.). Project Management. Moscow, Yurait Publ., 2019. 383 p.

25. Gatilin A.S. A "bad" example is contagious. "The editor of a newspaper in Zmeinogorsk taught residents to investigate and defend their rights. Takie dela, 2020, July 03. Available at: https://takiedela.ru/news/2020/07/03/lyudmila-keybol/ (In Russian).

26. Korkonosenko S.G. The Theory of Journalism: Modeling and Application. Moscow, Logos Publ., 2010. 247 p.

27. Svitich L.G. Journalism and Audience. From the Sociological Archive (1920-2015). Moscow, Ikar Publ., 2018. 486 p.

28. Grishchenko N., Ionova L. Putin promised the Rostov governor to help sort out the situation with the Vperyod newspaper.Rossiiskaya gazeta, 2020, December 17. Available at: https://rg.ru/2020/12/17/reg-ufo/putin-poruchil-glave-dona-razobratsia-v-dele-redaktoragazety-iz-batajska.html. (In Russian).

\section{ДЛЯ ЦИТИРОВАНИЯ}

Фролова Т.И. Социальные проекты муниципальных СМИ как инструмент развития местных сообществ и территорий: стартовые особенности / Т.И. Фролова, А.С. Гатилин. - DOI: 10.17150/2308-6203.2021.10(3).500-513 // Вопросы теории и практики журналистики. - 2021. - Т. 10, № 3. - С. 500-513. 
Вопросы теории и практики журналистики. 2021. Т. 10, № 3. С. 500-513

\section{FOR CITATION}

Frolova T.I., Gatilin A.S. Social Projects by Local Media as a Tool for the Development of Local Communities: Starting Points. Voprosy teorii $i$ praktiki zhurnalistiki $=$ Theoretical and Practical Issues of Journalism, 2021, vol. 10, no. 3, pp. 500-513. DOI: 10.17150/23086203.2021.10(3).500-513. (In Russian). 